\title{
Bioactive pyrones and flavonoids from Cryptocarya ashersoniana seedlings
}

\author{
Maria A. G. Ricardo, Márcio A. Andreo, Alberto J. Cavalheiro, Ian C. Gamboa, \\ Vanderlan S. Bolzani, and Dulce H. S. Silva* \\ Instituto de Química, Universidade Estadual Paulista, CP. 359, Araraquara, CEP 14800-900, \\ São Paulo, SP, Brazil \\ E-mail: dhsilva@,iq.unesp.br
}

\section{Dedicated to Professor Otto Richard Gottlieb}

(received 31 Jan 04; accepted 14 Sep 04; published on the web 19 Sep 04)

\begin{abstract}
The bioassay directed fractionation of the EtOH extract from leaves of Cryptocarya ashersoniana seedlings led to the isolation of two flavonol glucosides: iso-quercitrin and hyperin, which exhibited free radical scavenging activity towards $\mathrm{DPPH}\left(\mathrm{IC}_{50} 34.4 \mu \mathrm{M}\right.$ and 32.7 $\mu \mathrm{M}$, respectively) and were compared to standard compounds rutin ( $\left.\mathrm{IC}_{50} 27.0 \mu \mathrm{M}\right)$ and catechin $\left(\mathrm{IC}_{50} 41.4 \mu \mathrm{M}\right)$. Investigation of extracts from the seedlings roots and stems afforded one antifungal styrylpyrone: goniothalamine, and two dihydropyrones: 6-propyl-5,6-dihydro-2pyrone and the new 6-[(4'-ethyl-9'-oxabicyclo[3.3.1]non-6'-en-3'-yl)methyl]-5,6-dihydro-2Hpyran-2-one, which had its structure determined by detailed analysis of MS and NMR data, including $2 \mathrm{D}$ experiments.
\end{abstract}

Keywords: Cryptocarya ashersoniana, Lauraceae, pyrone, flavonoid, antioxidant, free radical scavenger, DPPH

\section{Introduction}

Cryptocarya genus belongs to Lauraceae family and comprises more than 350 species which occur in South America, Asia and Australia. Only three Cryptocarya species occurring in the Brazilian Atlantic Rain Forest have been chemically studied so far, and have shown to contain pyrones, flavonoids and alkaloids, in addition to sesquiterpenes in the essential oil. ${ }^{1-4}$ Alkaloids and pyrones are widely distributed in this genus in contrast to the chemical profile of Lauraceae family, in which lignans and neolignans are considered chemotaxonomical markers. ${ }^{5}$

Cryptocarya species have been used as traditional medicines in South Africa for their antiinflammatory and other activities. ${ }^{6,7}$ Some of the pyrones and styrylpyrones showed larvicidal and antifertility activities, in addition to inhibition of breast cancer cell lines growth. ${ }^{8-}$ 
${ }^{11}$ In this work, the chemical composition of $C$. ashersoniana seedlings has been assessed, in the search for bioactive compounds. Additionally, as the chemical profile of seedlings may be quite diverse from adult specimens, ${ }^{12}$ resulting from the developing enzymatic apparatus of the former, this work has also focused on chemical data to be used in chemical variability studies on Cryptocarya species currently performed in our lab. ${ }^{13}$ Seedlings of $C$. ashersonian were grown in our greenhouse and the extracts of their leaves, stems and roots were chemically investigated and led to the isolation of flavonol glucosides $\mathbf{1}$ and $\mathbf{2}$ from leaves, and pyrones 3-5 from stems and roots. Compounds 1-5 were tested against the phytopathogen fungi Cladosporium cladosporioides and C. sphaerospermum growth, and flavonol glucosides $\mathbf{1}$ and $\mathbf{2}$ were further evaluated for their free radical scavenging activities by spectrophotometric test using DPPH.

\section{Results and Discussion}

The EtOH extract from leaves of $C$. ashersoniana seedlings showed the presence of antioxidant compounds on the $\beta$-carotene test on TLC and afforded flavonol glucosides isoquercitrin (1) and hyperin (2), which were identified by MS and NMR spectral analysis and comparison with literature data. ${ }^{14-16}$ They showed moderate free radical scavenging activity ( $\mathrm{IC}_{50} 34.4 \mu \mathrm{M}$ and $32.7 \mu \mathrm{M}$ ), respectively when compared to standard compound rutin $\left(\mathrm{IC}_{50} 27.0\right.$ $\mu \mathrm{M})$ and higher activity than catechin $\left(\mathrm{IC}_{50} 41.4 \mu \mathrm{M}\right)$ (Figure 1), which is probably due to the $\alpha, \beta$-unsaturated carbonyl moiety conjugated to ring B and the catechol group. Compounds $\mathbf{1}$ and 2 showed no antifungal activity as they did not inhibit Cladosporium cladosporioides and $C$. sphaerospermum growth on TLC plates.<smiles>[R]c1c(-c2ccc(O)c(O)c2)oc2cc(O)cc(O)c2c1=O</smiles> 


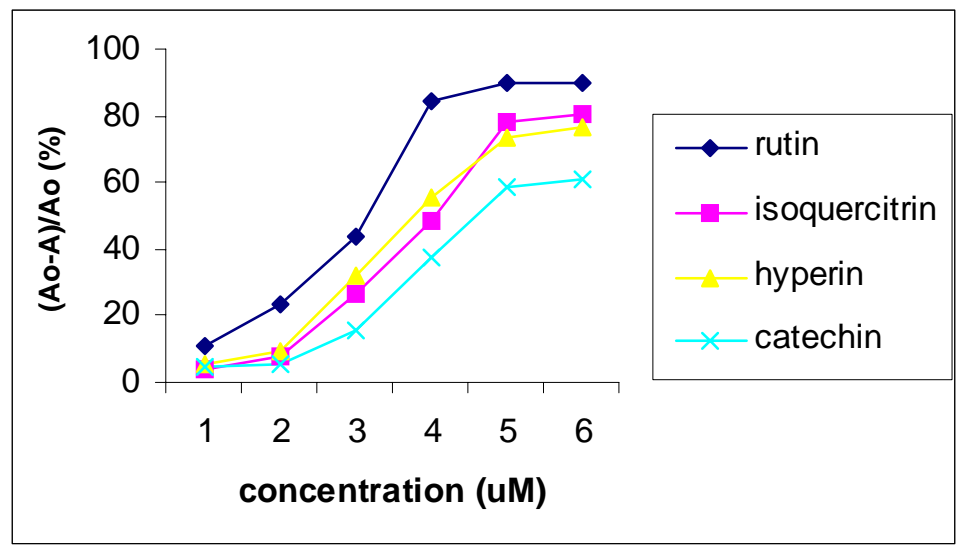

Figure 1. Free-radical scavenging activity of flavonol glucosides $\mathbf{1}$ and $\mathbf{2}$, and reference compounds rutine and catechin.

From the EtOH extract of stems and roots of $C$. ashersoniana seedlings, pyrones 3-5 were isolated and had their structures determination based on MS and NMR analysis, as well as comparison with literature data.

The ${ }^{1} \mathrm{H}$ NMR spectrum of compound 3 showed four signals at $\delta 5.65, \delta 5.71, \delta 5.95$ and $\delta$ 6.80 suggesting the presence of two disubstituted double bonds, including one $\alpha, \beta$-unsaturated carbonyl moiety; and three signals at $\delta 3.58, \delta 3.93$ and $\delta 4.30$, assigned to oxymethine hydrogens. The ${ }^{13} \mathrm{C}$ NMR spectrum of compound 3 showed five signals for $\mathrm{sp}^{2}$ carbons, including one $\alpha, \beta$-unsaturated carbonyl moiety and 11 signals for $\mathrm{sp}^{3}$ carbons, including three oxymethine carbons at $\delta 70.7, \delta 76.0$ and $\delta 77.8$. Combined with DEPT $135^{\circ}$ data, which evidenced only five methylene carbons, and MS data, which showed the molecular ion peak at $\mathrm{M}^{+}$. 262, the formula $\mathrm{C}_{16} \mathrm{H}_{22} \mathrm{O}_{3}$ was established, suggesting the structure of a pyrone ring attached to an unsaturated bicyclized $\mathrm{C}_{11}$ aliphatic chain. One triplet at $\delta 0.86(3 \mathrm{H})$, correlating to a multiplet at $\delta 1.50(2 \mathrm{H})$ in the HOMOCOSY spectrum and to signals at $\delta 11.9\left(\mathrm{C}-11^{\prime}\right)$ and $\delta$ $28.6\left(\mathrm{C}-10^{\prime}\right)$, in the HMQC and HMBC spectra, respectively, evidenced an ethyl unit, which is linked to a methine carbon $\left(\delta_{\mathrm{C}} 45.4, \delta_{\mathrm{H}} 1.75\right)$, assigned to $\mathrm{C}-4^{\prime}$, as shown by HMBC cross-peaks between H-11' and C-4', as well as by HOMOCOSY correlations of signals for H-4' and H-10'.

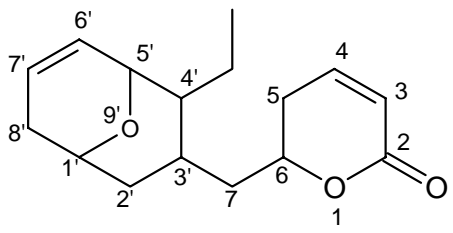

3<smiles>O=C1C=CCC(/C=C/c2ccccc2)O1</smiles>

4<smiles>CCC[C@H]1CC=CC(=O)O1</smiles>

5 
Table 1. - NMR data for compound $\mathbf{3}^{\mathrm{a}}$

\begin{tabular}{cccccc}
\hline Position & $\delta_{\mathrm{C}}{ }^{\mathrm{b}}$ & $\delta_{\mathrm{H}^{\mathrm{c}}}$ & $\mathrm{COSY}$ & $\mathrm{HMBC}$ & $\mathrm{TOCSY}$ \\
\hline 2 & $164.0 \mathrm{~s}$ & $-{ }^{2}$ & & & - \\
3 & $121.5 \mathrm{~d}$ & $5.95 \mathrm{dt}(2.0 ; 9.5)$ & $\mathrm{H}-4$ & $\mathrm{H}-5$ & $\mathrm{H}-4$ \\
4 & $144.8 \mathrm{~d}$ & $6.80 \mathrm{dt}(4.0 ; 9.5)$ & $\mathrm{H}-3 / \mathrm{H}-5$ & $\mathrm{H}-5$ & $\mathrm{H}-3$ \\
5 & $29.9 \mathrm{t}$ & $2.25 \mathrm{~m}$ & $\mathrm{H}-4 / \mathrm{H}-6$ & $\mathrm{H}-7$ & $\mathrm{H}-6 / \mathrm{H}-7 / \mathrm{H}-3^{\prime}$ \\
6 & $76.0 \mathrm{~d}$ & $4.30 \mathrm{br} \mathrm{tdd}(3.5 ; 7.8 ; 8.6)$ & $\mathrm{H}-5 / \mathrm{H}-3^{\prime}$ & $\mathrm{H}-7$ & $\mathrm{H}-5 / \mathrm{H}-7 / \mathrm{H}-3^{\prime}$ \\
7 & $41.7 \mathrm{t}$ & $1.90 \mathrm{~m}$ & $\mathrm{H}-3^{\prime} / \mathrm{H}-4^{\prime} / \mathrm{H}-8^{\prime}$ & $\mathrm{H}-7$ & $\mathrm{H}-2^{\prime} / \mathrm{H}-4^{\prime} / \mathrm{H}-5^{\prime}$ \\
$1^{\prime}$ & $70.7 \mathrm{~d}$ & $3.93 \mathrm{br} \mathrm{dq}(3.0 ; 7.0)$ & $\mathrm{H}-5^{\prime} / \mathrm{H}-8^{\prime}$ & $\mathrm{H}-5^{\prime}$ & $\mathrm{H}-5^{\prime} / \mathrm{H}-8^{\prime}$ \\
$2^{\prime}$ & $36.9 \mathrm{t}$ & $2.30 / 1.50 \mathrm{~m}$ & $\mathrm{H}-3^{\prime} / \mathrm{H}-7 / \mathrm{H}-8^{\prime}$ & $\mathrm{H}-7 / \mathrm{H}-3^{\prime}$ & $\mathrm{H}-3 / \mathrm{H}-6 / \mathrm{H}-7 /$ \\
& & & & $\mathrm{H}-2^{\prime} / \mathrm{H}-4^{\prime} / \mathrm{H}-8^{\prime}$ \\
$3^{\prime}$ & $37.5 \mathrm{~d}$ & $1.60 \mathrm{~m}$ & $\mathrm{H}-7 / \mathrm{H}-2^{\prime} / \mathrm{H}-6$ & $\mathrm{H}-7$ & $\mathrm{H}-5 / \mathrm{H}-6 / \mathrm{H}-1^{\prime} /$ \\
& & & & $\mathrm{H}-3^{\prime} / \mathrm{H}-8^{\prime}$ \\
$4^{\prime}$ & $45.4 \mathrm{~d}$ & $1.75 \mathrm{~m}$ & $\mathrm{H}-7 / \mathrm{H}-10^{\prime}$ & $\mathrm{H}-7 / \mathrm{H}-3^{\prime} \mathrm{H}-$ & $\mathrm{H}-7 / \mathrm{H}-10^{\prime} / \mathrm{H} 11^{\prime}$ \\
& & & $5^{\prime} / \mathrm{H}-11^{\prime}$ & \\
$5^{\prime}$ & $77.8 \mathrm{~d}$ & $3.58 \mathrm{t}(7.5)$ & $\mathrm{H}-1^{\prime} / \mathrm{H}-8$ & - & $\mathrm{H}-1^{\prime} / \mathrm{H}-8^{\prime}$ \\
$6^{\prime}$ & $130.5 \mathrm{~d}$ & $5.71 \mathrm{dt}(2 ; 11)$ & $\mathrm{H}-7^{\prime}$ & - & $\mathrm{H}-7^{\prime}$ \\
$7^{\prime}$ & $128.4 \mathrm{~d}$ & $5.65 \mathrm{ddd}(2 ; 3 ; 11)$ & $\mathrm{H}-6^{\prime}$ & - & $\mathrm{H}-6^{\prime}$ \\
$8^{\prime}$ & $33.9 \mathrm{t}$ & $3.14 \mathrm{br} \mathrm{dt}(2.0 ; 9.3) /$ & $\mathrm{H}-2^{\prime} / \mathrm{H}-8^{\prime}$ & - & $\mathrm{H}-2^{\prime} / \mathrm{H}-3^{\prime} / \mathrm{H}-5^{\prime} /$ \\
& & $1.90 \mathrm{~m}$ & & & $\mathrm{H}-8^{\prime}$ \\
$10^{\prime}$ & $28.6 \mathrm{t}$ & $1.50 \mathrm{~m}$ & $\mathrm{H}-4^{\prime} / \mathrm{H}-11^{\prime}$ & $\mathrm{H}-11^{\prime}$ & $\mathrm{H}-4^{\prime} / \mathrm{H}-11^{\prime}$ \\
$11^{\prime}$ & $11.9 \mathrm{q}$ & $0.86 \mathrm{t}(7.5)$ & $\mathrm{H}-10^{\prime}$ & $\mathrm{H}-10^{\prime}$ & $\mathrm{H}-4^{\prime} / \mathrm{H}-10^{\prime}$ \\
\hline
\end{tabular}

${ }^{\mathrm{a}} \mathrm{CDCl}_{3}, 500 \mathrm{MHz}$ and $125 \mathrm{MHz}$ for ${ }^{1} \mathrm{H}$ and ${ }^{13} \mathrm{C}$ NMR, respectively. Assignments were mostly based on HMQC and HOMOCOSY experiments.

${ }^{\mathrm{b}}$ multiplicities were obtained from DEPT $135^{\circ}$ experiment.

${ }^{\mathrm{c}} \delta$, multiplicity, $J(\mathrm{~Hz})$.

Two signals at $\delta 2.25(\mathrm{~m}, 2 \mathrm{H})$ and $\delta 4.30(\mathrm{br}$ tdd, $1 \mathrm{H})$ in the ${ }^{1} \mathrm{H}$ NMR spectrum were assigned to $\mathrm{H}-5$ and $\mathrm{H}-6$ of the pyrone ring, respectively, and showed correlations with signals at $\delta 29.9$ and $\delta 76.0$ in the HMQC spectrum, which were then assigned to the methylene $\mathrm{C}-5$ and oxymethine C-6, respectively. HMBC correlations of C-5 and C- 6 to methylene hydrogens at $\delta$ $1.90(\mathrm{H}-7)$ and, from the latter to the signals at $\delta 36.9\left(\mathrm{C}-2^{\prime}\right)$ and $\delta 37.5\left(\mathrm{C}-3^{\prime}\right)$, established the linkage between the pyrone ring and the bicyclic moiety (Figure 2). One triplet at $\delta 3.58$ and one broad double-quadruplet at $\delta 3.93$ for the two remaining oxymethine hydrogens, showing correlations with signals at $\delta 77.8\left(\mathrm{C}-5^{\prime}\right)$ and $\delta 70.7\left(\mathrm{C}-1^{\prime}\right)$ in the HMQC spectrum, suggested an unsaturated six-membered ring with an ether linkage, after observation of a cross-peak between the oxymethine hydrogens $\mathrm{H}-1^{\prime}(\delta 3.93)$ and $\mathrm{H}-5^{\prime}(\delta$ 3.58) in the HOMOCOSY and TOCSY spectra (Figure 3) as well as the HMBC correlation of $\mathrm{H}^{-} 5^{\prime}$ and $\mathrm{C}-1^{\prime}$ (Figure 2). The TOCSY spectrum showed correlations of signals at $\delta 1.75\left(\mathrm{H}-4^{\prime}\right), \delta 1.60\left(\mathrm{H}-3^{\prime}\right)$ and $\delta 1.90(\mathrm{H}-7)$, which 
suggested an additional cyclization between $\mathrm{C}-3^{\prime}$ and $\mathrm{C}-4^{\prime}$, leading to a bicyclic moiety. This explains further correlations, e.g. from $\mathrm{H}-7$ ( $\delta 1.90)$ and $\mathrm{H}-3^{\prime}(\delta 1.60)$ to $\mathrm{C}-4^{\prime}(\delta 45.4)$, observed in the HMBC spectrum; and a long distance correlation $\left(J^{4}\right)$ between $\mathrm{H}-7$ and $\mathrm{H}-4^{\prime}$ in the HOMOCOSY spectrum. Additional HMBC and HOMOCOSY correlations confirmed the proposed structure for compound 3 (Table 1). The relative configuration of asymmetric centers C-1', C-3', C-4' and C-5' was established by analysis of coupling constants, e.g. $J_{\mathrm{H}-4^{\prime} / \mathrm{H}-5^{\prime}}=7.5$ $\mathrm{Hz}$, which evidenced the cis relationship of $\mathrm{H}-4^{\prime}$ and $\mathrm{H}-5^{\prime}$; and additionally by NOESY experiments, which showed correlations between $\mathrm{H}-3^{\prime} / \mathrm{H}-4^{\prime}$ and $\mathrm{H}-4^{\prime} / \mathrm{H}-5^{\prime}$, and confirmed the $c$ is orientation for these hydrogens. The cis relationship of $\mathrm{H}-1^{\prime} / \mathrm{H}-5^{\prime}$ was assumed due to high steric hindrance of the $\left(\mathrm{H}-1^{\prime} / \mathrm{H}-5^{\prime}\right)$ trans isomer, as observed by molecular modeling and theoretical studies on steric energy minimization using the MM2 software and on heats of formation using the semiempirical PM3 and AM1 methods on SCF-MO-MOPAC-2000 software. ${ }^{17}$ A positive Cotton effect due to the carbonyl $n \rightarrow \Pi^{*}$ transition of the $\alpha, \beta$-unsaturated- $\delta$-lactone moiety was observed at $\lambda_{\max } 255 \mathrm{~nm}(\Delta \varepsilon+2.84)$ in the CD spectrum of 3 . This observation indicated that the absolute configuration a C-6 was (S) on the basis of the rule first proposed by Snatzke ${ }^{18}$ and later modified by Beecham, ${ }^{19}$ considering the conformation of the $\alpha$-pyrone ring, which was inferred due to steric factors. ${ }^{20}$ These observations led to the establishment of the new pyrone as $1^{\prime} R^{*}, 3^{\prime} S^{*}, 4^{\prime} R^{*}, 5^{\prime} S^{*}, 6 S-6$-[4'-ethyl-9'-oxabicycle[3.3.1]non-6'-en-3'-yl)methyl]-5,6-dihydro-2Hpyran-2-one.

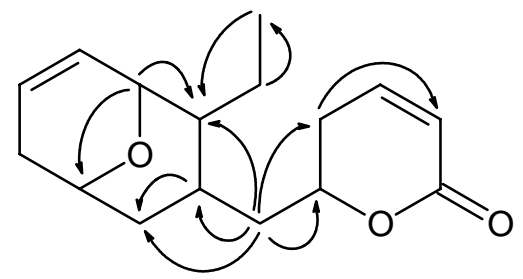

Figure 2. Selected HMBC correlations for compound 3.

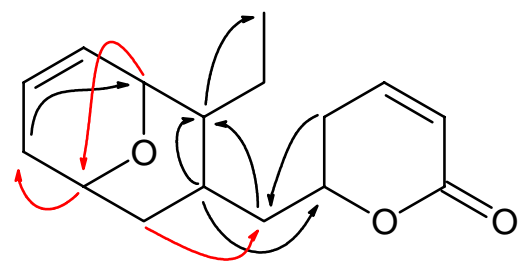

Figure 3. Selected HOMOCOSY (red arrows) and TOCSY (black arrows) correlations for compound $\mathbf{3}$. 


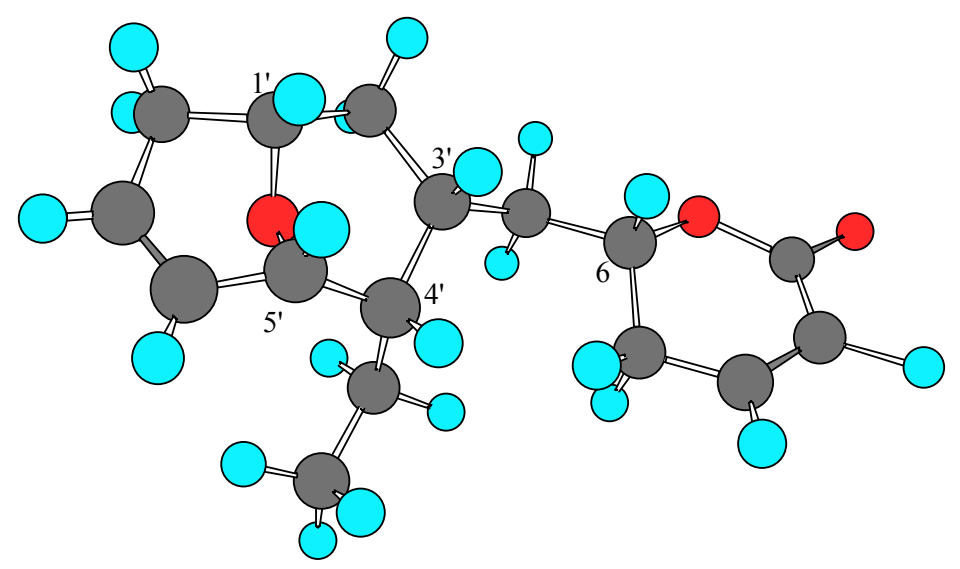

Figure 4. Structure of pyrone 3 evidencing the cis relationship of $\mathrm{H}-1^{\prime}, \mathrm{H}-3^{\prime}, \mathrm{H}-4^{\prime}$ and $\mathrm{H}-5^{\prime}$.

The biogenetic pathway leading to this novel pyrone was proposed, in which an acetate derived $\mathrm{C}_{16}$ chain has gone through cyclization reactions to originate the pyrone ring via nucleophyllic attack followed by dehydration steps (Scheme 1). The subsequent attack of HO-5' onto $\mathrm{C}-1^{\prime}$ with the ring closure via an ether linkage followed by dehydration and reduction steps might yield intermediate $\mathbf{8}$. Two additional dehydration steps would yield intermediate $\mathbf{9}$, which might go through a final cyclization, resulting from nucleophilic attack of C-4' onto C-3', and the subsequent formation of compound 3. Bicyclic pyrones resulting from cyclization of the sidechain onto the $\alpha, \beta$-unsaturated carbonyl ring as cryptocaryolone (10) and goniopyrone (11) have been reported solely from other Cryptocarya (Lauraceae) and Goniothalamus (Annonnaceae) species, respectively ${ }^{21,22}$ and led to structures in which the pyrone C-C double bond is lost. Compound $\mathbf{3}$ differs from those as the driving force for both cyclization steps do not involve the $\alpha, \beta$-unsaturated carbonyl moiety of the pyrone ring. Conversely, nucleophylic attacks, dehydration and reduction reactions involving hydroxy groups and double bonds in the sidechain led to a bicyclic structure linked to an intact pyrone moiety. 
<smiles>CC(=O)CC(=O)CC(=O)CC(=O)CC(=O)CC(=O)CC(=O)CC(=O)O</smiles><smiles>CCCCCCCCCCC(=O)CC(=O)CC1CC=CC(=O)O1</smiles>

7<smiles>CCC1OC2CC=CC1C(CC1CC=CC(=O)O1)C2</smiles>
3<smiles>CCC1CC(CC(O)CC2CC=CC(=O)O2)OC(CC(C)O)C1O</smiles><smiles>CC=CC1C=CCC(CC(O)(CC)CC2CC=CC(=O)O2)O1</smiles>

9

Scheme 1. Biogenetic proposal for compound 3.

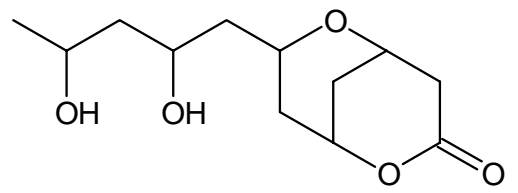

10

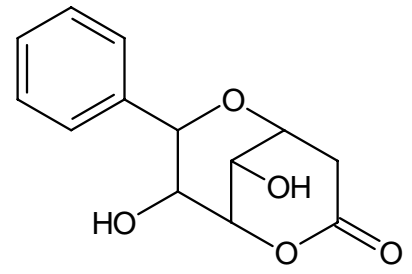

11

Compound 4 was identified with goniothalamine, previously isolated from Goniothalamus macrophyllus (Annonnaceae), from the bark of Cryptocarya caloneura and C. moschata ${ }^{23,24}$ and from leaves of $C$. ashersoniana. ${ }^{25}$ It showed CNS activity and induced fetal abnormalities in rats. ${ }^{26,27}$ Compound 5 was identified with 5,6-dihydro-6-propyl-2H-pyrane-2-one, which had been isolated previously from the fungus Lasiodiplodia theobromae, growing on fruits of Palmae species ${ }^{28}$ and is now reported for the first time from a plant species. Compounds 3-5 were assayed for antifungal activity by bioautography with phytopathogen fungi Cladosporium cladosporioides and C. sphaerospermum. ${ }^{29}$ Compound $\mathbf{5}$ showed moderate activity on the TLC assay and had its MIC further determined $(8 \mu \mathrm{g})$ and compared to standard fungicidal compounds nystatin (MIC $0.5 \mu \mathrm{g}$ ) and myconazol (MIC $0.5 \mu \mathrm{g}$ ). 


\section{Experimental Section}

General Procedures. Silica gel (Merck, 230-400 and 70-230 Mesh), Sephadex LH-20 (Pharmacia) and polyvinylpolypyrrolidone (PVPP) were used for column chromatography unless otherwise stated and solvents were redistilled prior to use. NMR spectra were recorded on Bruker AC-200 or Varian INOVA 500 spectrometers at 200 or $500 \mathrm{MHz}$, respectively, for ${ }^{1} \mathrm{H}$ NMR, and at 50 or $125 \mathrm{MHz}$, respectively, for ${ }^{13} \mathrm{C}$ NMR, with TMS as internal standard and DMSO- $d_{6}$ or $\mathrm{CDCl}_{3}$ as solvent. ES-MS were recorded on a VG Platform II spectrometer and elemental analysis was performed on a Perkin-Elmer Analyser model 2400CHN. Theoretical study was done using the semiempirical PM3 and AM1 methods on SCF-MO-MOPAC-2000 software. CD curves were obtained using a ISA Jobin Yvon CD6 dichrograph and optical rotation was measured on a Perkin-Elmer 241 polarimeter using a quartz cuvette (length $1 \mathrm{~cm}$ ).

Plant material. Seedlings of $C$. ashersoniana were grown in the greenhouse at Chemistry Institute, Sao Paulo State University in Araraquara, Brazil and were harvested when the seedlings were ca. 10 months old and $45 \mathrm{~cm}$ high.

Extraction and isolation. Leaves, stems and roots were dried at $40^{\circ} \mathrm{C}$ and ground separately. Each plant material was extracted with ethanol, which was then evaporated under vacuum and afforded the EtOH extracts of leaves $(30.7 \mathrm{~g})$, stems $(3.7 \mathrm{~g})$ and roots $(16.7 \mathrm{~g})$. The EtOH extract from leaves $(10.0 \mathrm{~g})$ was partitioned with organic solvents o afford the hexane $(4.6 \mathrm{~g})$, chloroform $(1.1 \mathrm{~g})$, EtOAc $(3.3 \mathrm{~g})$ and hydroalcoholic $(0.3 \mathrm{~g})$ fractions. The EtOAc fraction ( $3.0 \mathrm{~g})$ was applied to a Sephadex LH-20 column (300.0 g), eluted with $\mathrm{MeOH}$ to give 10 fractions. Fraction 7 (0.234 g) was submitted to HPLC separation (RP-18; $\mathrm{MeOH} / \mathrm{H}_{2} \mathrm{O}$ 72:28; flow $9 \mathrm{~mL} / \mathrm{min}$; UV detection at $280 \mathrm{~nm})$ and afforded compounds $1(12 \mathrm{mg})$ and $\mathbf{2}(7 \mathrm{mg})$. The EtOH extract ( $8.2 \mathrm{~g}$ ) of roots and stems were combined after comparison by TLC analysis and submitted to MPLC ( $\mathrm{RP}-18, \mathrm{H}_{2} \mathrm{O} / \mathrm{MeOH}$ gradient), affording 11 pooled fractions (A-K). Fraction E $(830 \mathrm{mg}$ ) was submitted to MPLC (silica gel, hexane/EtOAc gradient) and afforded 14 fractions (E1-E14). Fractions E4 $(39 \mathrm{mg})$ and E9 $(48 \mathrm{mg})$ were further purified by preparative TLC $\left(\mathrm{CH}_{2} \mathrm{Cl}_{2} / \mathrm{MeOH} /\right.$ iso-PrOH $\left.97: 2: 1\right)$ and yielded compounds $4(16 \mathrm{mg})$ and $5(8 \mathrm{mg})$, respectively. Fraction G $(480 \mathrm{mg}$ ) was also submitted to MPLC (silica gel, hexane/EtOAc gradient) and afforded 9 fractions (G1-G9). Fraction G6 $(27 \mathrm{mg})$ was purified by HPLC (RP-18; $\mathrm{MeOH} / \mathrm{H}_{2} \mathrm{O}$ 87:13; flow $9 \mathrm{~mL} / \mathrm{min}$; UV detection at $240 \mathrm{~nm}$ ) and afforded compound $3(6 \mathrm{mg})$.

Compound 3. $1^{\prime} R^{*}, 3^{\prime} S^{*}, 4^{\prime} R^{*}, 5^{\prime} S^{*}, 6 S-6-\left[\left(4^{\prime}\right.\right.$-ethyl-9'-oxabicycle[3.3.1]non-6'-en-3'-yl)methyl]- 5,6dihydro-2H-pyran-2-one. Brown oil, $\mathrm{C}_{16} \mathrm{H}_{22} \mathrm{O}_{3}$ (calc. $73.25 \% \mathrm{C}, 8.45 \% \mathrm{H}$; obs. $73.21 \% \mathrm{C}$; 8.48\% $\mathrm{H}) ;[\alpha]_{\mathrm{D}}^{25}=+57.7^{\circ}\left(\mathrm{CHCl}_{3}, c 0.52\right) ; \Delta \varepsilon_{\operatorname{Max}}(255 \mathrm{~nm})=2.84(\mathrm{MeOH}, \mathrm{c} 2.0) ;$ ESIMS, m/z (rel. int.) (40V, positive mode): $285[\mathrm{M}+\mathrm{Na}]^{+}(100), 263[\mathrm{M}+\mathrm{H}]^{+}(35), 262[\mathrm{M}]^{+}(17) .{ }^{1} \mathrm{H}$ and ${ }^{13} \mathrm{C}$ NMR spectral data, see Table 1.

Bioautography with phytopathogen fungi on TLC plates. ${ }^{25}$ Each sample is submitted to TLC analysis and, after dry, the plate is sprayed with Cladosporium cladosporioides or $C$. sphaerospermum spore solution. The plates are kept at $25^{\circ} \mathrm{C}$ in the dark for $2-3$ days, when the 
fungi grow all over the plates, except for spots where antifungal compounds are present, which remain white. The inhibition zones are measured and compared to standard compounds nystatin and myconazol.

Bleaching experiments on $\boldsymbol{\beta}$-carotene. ${ }^{26}$ Each extract (ca. $10 \mu \mathrm{g}$ ) was assayed for the presence of antioxidants using a TLC test and two eluents $\left(\mathrm{CHCl}_{3} / \mathrm{MeOH} 7: 3\right.$ and hexane/EtOAc 1:1). After developing and drying, TLC plates were sprayed with a $0.02 \%$ solution of $\beta$-carotene (Aldrich) in $\mathrm{CH}_{2} \mathrm{Cl}_{2}$. Plates were placed under natural light until discoloration of background. The remaining yellow spots indicated the presence of antioxidant substances.

Spectrophotometric assay on the reduction of 2,2-diphenyl-1-picrylhydrazyl radical. ${ }^{27}$ Reaction mixtures containing test samples (dissolved in $\mathrm{MeOH}$ ) at several concentrations and $0.004 \%$ DPPH methanolic solutions were incubated at $25^{\circ} \mathrm{C}$ for $30 \mathrm{~min}$. Absorbances of the resulting solutions were measured using a Milton Roy 20D spectrophotometer at $517 \mathrm{~nm}$ and the percent inhibition was determined by comparison with a $\mathrm{MeOH}$ treated control group.

\section{Acknowledgments}

This work was funded by grants of the State of São Paulo Research Foundation (FAPESP) within the Biota-FAPESP - The Biodiversity Virtual Institute Program (www.biotasp.org.br); Grant \# 98/05074-0. MAGR and MAA thank FAPESP for providing them scholarships.

\section{References}

1. Cavé, A.; Leboeuf, M.; Moskowitz, H.; Ranaivo, A.; Bick, I. R. C.; Sinchai, W.; Nieto, M.; Sevenet, T.; Cabalion, P. Austr. J. Chem. 1989, 42, 2243.

2. Naves, Y. R.; Arndt, V. H.; Magalhães, M. T.; Gottlieb, O. R.; Alves, H. M. Helv. Chim. Acta 1963, 46, 1056.

3. Spencer, G. F.; England, R. E.; Wolf, R. B. Phytochemistry 1984, 23, 2499.

4. Govindac,T. R.; Parthasa, P. C.; Desai, H. K.; Shanbhag, M. N. Tetrahedron 1973, $29,3091$.

5. (a) Gottlieb, O. R. Phytochemistry 1972, 11, 1537. (b) Gottlieb O. R. Abstr. Papers Am. Chem. Soc. 1971, A, 83. (c) Gottlieb, O.G.; Yoshida, M. In Natural Product of Wood Plants; Rowe, J. W., Ed.; Springer-Verlag: Berlin, 1989; p 439.

6. Zschocke, S.; van Staden, J. J. Ethnopharmacol. 2000, 71, 473.

7. Drewes, S. E.; Horn, M. H.; Mavi, S. Phytochemistry 1997, 44, 437.

8. Hawariah, A.; Stanslas, J. Anticancer Res. 1998, 18, 4383.

9. Pihie, A. H. L.; Stanslas, J.; Bin Din, L. Anticancer Res. 1998, 18, 1739.

10. Ee, Y. S.; Lai, L. C.; Reimann, K.; Lim, P. K. C. Oncology Reports 1999, 6, 843.

11. Hawariah, L. P. A.; Munawer, M.; Din, L.B. Asia Pacific J. Pharmacol. 1994, 9, 273. 
12. Lopes, N. P.; Franca, S. C.; Pereira, A. M. S, Maia, J. G. S.; Kato, M. J.; Cavalheiro, A. J.; Gottlieb, O. R.; Yoshida, M. Phytochemistry 1994, 35, 1469.

13. Nehme, C. J.; Moraes, P. L. R.; Cavalheiro, A. J. Biochem. Syst. Ecol. 2002, 30, 613.

14. Agrawal, P. K.; Bansal, M. C. Carbon-13 NMR of Flavonoids; Elsevier: Amsterdam, 1989

15. Douglass, C. D.; Howard, W. L.; Wender, S. H. J. Am. Chem. Soc. 1949, 71, 2658.

16. Nair, G. V.; Vonrudloff, E. Can. J. Chem-Revue Canadienne de Chimie 1960, 38, 2531.

17. Stewart, J. J. P. MOPAC 2000; Fujitsu Limited: Tokyo, Japan, 1999.

18. Snatzke, G. Angew. Chem., Internat. Edit. 1968, 7, 14.

19. Beecham, A. F. Tetrahedron 1972, 28, 5543.

20. Davis-Coleman, M. T.; Rivet, D. E. A. Progress Chem. Org. Nat. Prod. 1989, 55, 1.

21. Drewes, S. E.; Sehlapelo, B. M.; Horn, M. M.; Shaw, R. S.; Sandor, P. Phytochemistry 1995, 38, 1427. Drewes, S. E.; Horn, M. M.; Shaw, R. S. Phytochemistry 1995, 40, 321.

22. Fang, X. P.; Anderson, J. E.; Chang, C. J.; Fanwick, P. E.; Mclaughlin, J. L. J. Chem. Soc. Perkin Trans. 1, 1990, 1655.

23. Hlubucek J.R.; Robertso, A. U. Austr. J. Chem. 1967, 20, 2199.

24. Cavalheiro A. J.; Yoshida, M. Phytochemistry 2000, 53, 811.

25. Bastos, W. L. Ph.D. Thesis, Chemistry Institute, São Paulo State University, Brazil, 2003.

26. Jewers, K.; Blunden, G, Wetchapi, S, Dougan, J, Manchand, A. H.; Davis, J. B.; Kyi, A. Phytochemistry 1972, 11, 2025.

27. Sam, T. W, Chew, S. Y.; Matsjeh, S.; Gan, E. K.; Razak, D.; Mohamed, A. L. Tetrahedron Lett. 1987, 28, 2541.

28. Matsumoto, M.; Nago, H. Biosci. Biotech. Biochem. 1994, 58, 1262.

29. Homans, A. L.; Fuchs, A.; J.Chromat. 1970, 51, 325.

30. Pratt, D. E.; Miller, E. E. J Am Oil Chem Soc 1984, 61, 1064.

31. Blois, M. S. Nature 1958, 181, 1199. 